\title{
Development of microsatellite markers for Rhodiola rosea
}

\author{
Veress, A., Lendvay, B., Pedryc, A. \& György, Z. \\ Corvinus University of Budapest, Faculty of Horticultural Science, Department of Genetics and Plant Breeding, \\ Villányi út 29-43, 1118, Budapest, Hungary
}

\begin{abstract}
Summary: Rhodiola rosea L. is an important adaptogen medicinal plant. In this study two new microsatellite markers were developed. The assessment of the genetic diversity of $R$. rosea has recently started with molecular markers, but only a few species-specific microsatellite markers have been published so far. However the small number of markers allows only a limited insight into the genetic variability of the species therefore the aim of our work was to develop new microsatellite markers for $R$. rosea with a microsatellite enrichment library technique. Genomic DNA was cleaved with an endonuclease enzyme followed by adaptor ligation and PCR amplification. DNA fragments that contained microsatellites were first isolated using a biotin-streptavidin linkage based magnetic selection and then cloned into plasmids. Out of forty-three sequenced clones three contained microsatellites, in these cases primers were designed for the amplification of the microsatellite repeats. The newly developed primer pairs were tested on individuals from distant $R$. rosea populations and the variability of the amplified fragments was estimated by fragment-length analysis. The locus RhpB14a was found to be monomorphic while RhpB14b and RhpB13 were polymorphic. As a result of the present study, two novel variable microsatellite loci were identified in the genome of $R$. rosea.
\end{abstract}

Keywords: adaptogen, microsatellite marker, aromatic plant, population genetic, Rhodiola rosea

\section{Introduction}

Rhodiola rosea L. (roseroot or golden root) is a popular plant in traditional medicine because of its adaptogen properties. Adaptogenic herbs contain active substances that neutralize physical, chemical and biological stressors. Rhodiola rosea has a positive effect on cardiovascular functions as well as the ability to stimulate the central nervous system (Kelly, 2001). Because of the antioxidant and anti-psychotic effects of $R$. rosea, the extract is used to treat tiredness, depression, anemia, impotence, infections, longevity, high altitude sickness, neural disorders, in addition to increasing physical endurance and work productivity (Brown et al., 2002). The demand for products containing $R$. rosea is high. They are mainly taken to reduce physical fatigue and increase mental performance (Blomkvist et al., 2009). Studies focusing on roseroot-based products demonstrated its positive impacts on nervous-, heart- and vascular system disorders as well as its anti-fatigue, antidepressant and sedative effects. As a dietary supplement it is used worldwide (Panossian et al., 2010).

Rhodiola rosea belongs to the family of Crassulaceae, to the subfamily Sedoideae and to the genus Rhodiola (Ohba, 1981). Rhodiola rosea is a dioecious plant that reaches a height of 30 to $80 \mathrm{~cm}$ and produces yellow flowers (Khanum et al., 2005) from April to August (Tasheva \& Kosturkova, 2012). It is a perennial plant with thick rhizome which has a rose-like fragrance when cut (Khanum et al., 2005). The average weight of the rhizomes is $70-400 \mathrm{~g}$, but a weight of $3.5 \mathrm{~kg}$ can be reached. Leaves are oblong and elliptical in shape (Tasheva \& Kosturkova, 2012). The genus Rhodiola originated from mountainous areas of South-West China and the Himalayas (Ohba, 1989). Rhodiola rosea is distributed in high mountains and in subpolar regions of the northern hemisphere (Hegi, 1963).

Due to the intensive collection of its roots and rhizome the species has become extinct in some native habitats while in others the size of its population has been greatly reduced (Chiorghita et al., 2011). The increased demand for its herbal drugs and decline of its natural populations justified the cultivation of $R$. rosea (Galambosi, 2005). The first steps during its breeding work include the collection and characterization of the naturally occurring genotypes morphologically and phytochemically. Interand intrapopulation genetic diversity can be described by molecular markers.

The DNA based markers are DNA segments that can be used for detecting differences in the genome and are not necessarily manifested in the phenotype (Agarwal et al., 2008). Molecular markers also provide an opportunity to assess genetic diversity: recently, they have played an essential role in studying variability, diversity (Behera et al., 2008), and in various breeding programs (Gupta et al., 2001). Microsatellites or Simple Sequence Repeats (SSRs) are tandem repeat motifs of 1-6 bases, which are present in prokaryotic and eukaryotic genomes similarly, both in coding and non-coding regions ( $W u$ et al., 1994; Agarwal et al., 2008). Microsatellites have an important role among the DNA based markers due to their abundance and hyper variability (Gupta et al., 1996). These markers are wellreproducible and show co-dominant inheritance and multiallelic properties (Agarwal et al., 2008).

In case of $R$. rosea the number of SSR markers is limited. In 2009 Zini et al. developed eight microsatellite (SSR) primers specific to $R$. rosea. Four of these have been 
used by Kylin (2010) studying Scandinavian roseroot populations. During the work of György et al. (2014) only four out of these eight SSR markers proved to be informative. You et al. (2013) have published SSR markers, but those were not developed for roseroot, but for other Rhodiola species. The four most polymorphic was chosen and tested on R. rosea by György et al. (2014) and two were found to be applicable on that species. However this small number of SSR markers does not provides sufficient genetic resolution for population genetic studies. Therefor the aim of our work was to develop new, $R$. rosea specific SSR markers.

\section{Materials and methods}

\section{Plant material}

Plant material originated from the collection of the Department of Genetics and Plant Breeding of Corvinus University of Budapest. The plant material was collected in Austria, Norway, Italy, Russia, Switzerland and Slovenia (Table 1) and was identified by collegues from the Department of Botany, CUB.

\section{DNA extraction}

DNA was extracted from frozen leaves of $R$. rosea (2/183, 2/186, 2/187, 2/189, M3, M13, M15, S5, S11, S15) using E.Z.N.A. SP Plant Mini Kit (Omega, VWR, Budapest, Hungary) according to the manufacturer's instructions. DNA quality and quantity was measured respectively by ethidiumbromide stained 1\% TBE agarose gel electrophoresis and NanoDrop ND 1000 spectrophotometer (NanoDrop Technologies, Bioscene, Budapest, Hungary).

\section{FIASCO (Fast isolation by AFLP of sequences containing repeats)}

The development of microsatellite markers was executed by the FIASCO (Fast Isolation by AFLP of Sequences COntaining repeats) method described by Zane et al. (2002) and Bloor et al. (2001) and shown in Figure 1. In the first step (Figure 1. 1. step ) the S5 (Triglav, Slovenia) genomic DNA sample was cleaved with TrulI restriction endonuclease. The reaction mixture contained $1 \times$ buffer $\mathrm{R}$ (Fermentas, Biocenter, Szeged, Hungary), 1 U TrulI restriction enzyme (Fermentas, Biocenter, Szeged, Hungary), $8 \mu \mathrm{l}$ (ca. $2 \mu \mathrm{g}$ )

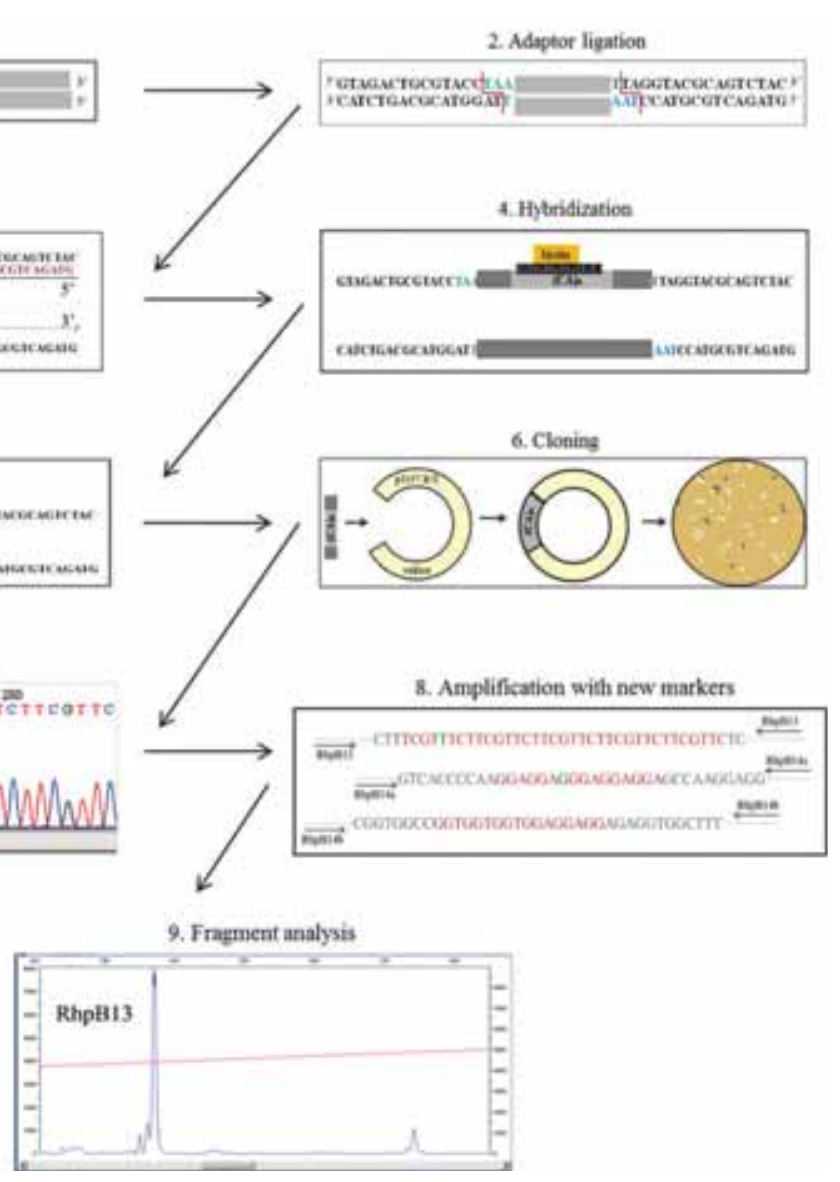

genomic DNA in a final volume of $20 \mu \mathrm{l}$. After the digestion DNA was purified using chloroform, precipitated with $7.5 \mathrm{M}$ ammonium acetate and finally the DNA was dissolved in 15 $\mu \mathrm{l}$ of distilled water.

Adaptors TrulI top and TrulI bottom (see nucleotid sequence in Table 2, Figure 1. 2. step) were ligated to the restriction enzyme generated sticky ends. Ligation was performed in a final volume of $20 \mu \mathrm{l}$ containing $10 \mu \mathrm{l}$ $2 \times$ buffer, $2 \mu \mathrm{l}$ TrulI adaptor, 5 U T4 DNA ligase (Fermentas, Biocenter, Szeged, Hungary), $5 \mu$ digested and purified DNA and $2 \mu \mathrm{l}$ sterile water. The ligation lasted for 1 hour at $25^{\circ} \mathrm{C}$ and was followed by chloroform purification as previously described. The resulting fragments were amplified by PCR (Swift MaxPro, Esco Micro Pte. Ltd, Singapore). The $20 \mu \mathrm{l}$ reaction volume contained $10 \times \mathrm{PCR}$ buffer, $2.5 \mathrm{mM} \mathrm{MgCl}_{2}$, $0.02 \mathrm{mM}$ dNTP mix, $2.5 \mathrm{mM}$ TrulI top, adaptor-specific primer, $0.5 \mu \mathrm{l} \mathrm{BSA} \mathrm{(1} \mathrm{mg/ml),} \mathrm{0.5} \mathrm{U} \mathrm{Taq} \mathrm{DNA} \mathrm{polymerase}$ (Fermentas, Biocenter, Szeged, Hungary), $1.5 \mu \mathrm{l}$ digested DNA and $11.64 \mu \mathrm{l}$ distilled water (Figure 1. 3. step). The following thermal profile was used: initial denaturation at $94^{\circ} \mathrm{C}$ for $5 \mathrm{~min}$, followed by 25 cycles of $94^{\circ} \mathrm{C}$ for $30 \mathrm{sec}$, $52^{\circ} \mathrm{C}$ for $30 \mathrm{sec}$ and $72^{\circ} \mathrm{C}$ for $45 \mathrm{sec}$ and a final extension at $72^{\circ} \mathrm{C}$ for $7 \mathrm{~min}$.

Selection of the $(\mathrm{CA})_{\mathrm{n}}$ containing fragments was carried out according to Bloor et al. (2001) (Figure 1. 4. step). The reaction components included $2.5 \mu \mathrm{l}$ of $10 \mu \mathrm{M} 5$ ' biotinlabelled $(\mathrm{GT})_{5}$ oligonucleotide, $6 \mu \mathrm{l}$ amplified product 
and $11.5 \mu \mathrm{l}$ sterile water. The mixture was heated to $94^{\circ} \mathrm{C}$ for $7 \mathrm{~min}$, the DNA was denatured then the temperature was decreased by $0.1^{\circ} \mathrm{C} / \mathrm{sec}$ ramping speed to promote the hybridization of biotin-labelled fragments to the complementary strands. In a subsequent step (Figure 1. 5. step), the resulting product was subjected to magnetic selection. At the beginning of the process, pre-washing and pre-blocking steps were carried out. First, $10 \mu \mathrm{l}$ streptavidincoated magnetic beads (Dynabeads M-280 streptavidin, Life Technologies Corporation, Invitrogen, Carlsbad, California) was added into a $1.5 \mathrm{ml}$ centrifuge tube and mixed thoroughly. In a second step the tube was placed next to a magnetic stand for $2 \mathrm{~min}$ to allow the beads to migrate to the side of the tube, and the supernatant was removed. In the third step $20 \mu \mathrm{l} 1 \times$ Washing/Binding (W/B) buffer (10 $\mathrm{mM}$ Tris- $\mathrm{HCl}$ ( $\mathrm{pH} 7.5$ ), $1 \mathrm{mM}$ EDTA, $2 \mathrm{M} \mathrm{NaCl}$ ) was added and magnetic beads were suspended. The second and the third step were repeated. Next, $20 \mu \mathrm{l} 2 \times \mathrm{W} / \mathrm{B}$ buffer and 20 $\mu \mathrm{l}$ inert PCR products were measured into the tube. After 5 min the tube was placed to a magnetic stand for $2 \mathrm{~min}$ and the supernatant was removed. After these pre-washing and preblocking steps $20 \mu \mathrm{l} 2 \times \mathrm{W} / \mathrm{B}$ buffer, $10 \mu \mathrm{l}$ cleaved DNA with adaptors, $2 \mu \mathrm{l}$ inert PCR products and $8 \mu \mathrm{l}$ distilled water were added to the pellet. All was suspended for $15 \mathrm{~min}$ then placed to the magnetic stand for $2 \mathrm{~min}$ followed by aspiration of the supernatant. Other $37 \mu \mathrm{l} 1 \times \mathrm{W} / \mathrm{B}$ buffer and $3 \mu \mathrm{l}$ inert PCR products were measured into the centrifuge tube. The solution was swirled for $5 \mathrm{~min}$ then the tube was put into the magnetic pole again. After removing the supernatant, 37 $\mu \mathrm{l} 1 \times \mathrm{W} / \mathrm{B}$ buffer and $3 \mu \mathrm{l}$ inert PCR products were added to the system and the tube was shaken for $20 \mathrm{~min}$. The tube was placed into the magnetic column for $3 \mathrm{~min}$ and the transparent liquid was removed. Finally, the content of the tube was dissolved in $25 \mu \mathrm{TE}(10 \mathrm{mM}$ Tris- $\mathrm{HCl} \mathrm{pH} 8.0$, $0.1 \mathrm{mM}$ EDTA) buffer and $2.5 \mu \mathrm{l}$ distilled water. In the next step, the resulted fragments were amplified by the previously described PCR. The following components were mixed in a final volume of $40 \mu \mathrm{l}: 4 \mu \mathrm{l} 10 \times$ buffer (Fermentas, Biocenter, Szeged, Hungary), $1.9 \mu \mathrm{l} 25 \mathrm{mM} \mathrm{MgCl}, 0.8 \mu \mathrm{l} 10 \mathrm{mM}$ dNTP mix, $6.4 \mu \mathrm{l} 10 \mu \mathrm{M}$ TrulI top primer, $1 \mu \mathrm{l}$ BSA $(1 \mathrm{mg} / \mathrm{ml})$, 1 U Taq DNA polymerase (Fermentas, Biocenter, Szeged, Hungary), $3 \mu \mathrm{l}$ DNA of the selected fragments and $21.9 \mu \mathrm{l}$ distilled water. The PCR program consisted of denaturation for $6 \mathrm{~min}$ at $94^{\circ} \mathrm{C}$, followed by 30 cycles of $94^{\circ} \mathrm{C}$ for $30 \mathrm{sec}$, $52^{\circ} \mathrm{C}$ for $30 \mathrm{sec}$ and $72^{\circ} \mathrm{C}$ for $45 \mathrm{sec}$ and the final extension at $72^{\circ} \mathrm{C}$ for $30 \mathrm{~min}$. The success of the reaction was evaluated by gel electrophoresis.

\section{DNA sequencing}

The amplified DNA fragments were ligated into pTz57R/T vector using InsTA Clone PCR Cloning Kit (Fermentas, Biocenter, Hungary) (Figure 1.6. step). The ligated plasmids were transformed into DH5 $\alpha$ competent cells and blue-white screen technique (Padmanabhan et al., 2010) was applied. Plasmid DNA was isolated from recombinant colonies using E.Z.N.A. Plasmid Mini Kit (Omega, CA, USA) and
Table 1. Plant material

\begin{tabular}{|c|c|}
\hline Code & Origin \\
\hline $2 / 183$ & Northern-Norway \\
\hline $2 / 186$ & Northern-Norway \\
\hline $2 / 187$ & Northern-Norway \\
\hline $2 / 189$ & Northern-Norway \\
\hline $9 / 134$ & Northern-Norway \\
\hline $9 / 134$ & Northern-Norway \\
\hline $10 / 111$ & Northern-Norway \\
\hline A3 & Prabichl, Austria \\
\hline $\mathrm{B} 2$ & Binntal, Switzerland \\
\hline B3 & Binntal, Switzerland \\
\hline M13 & Mattmark, Switzerland \\
\hline M15 & Mattmark, Switzerland \\
\hline M3 & Mattmark, Switzerland \\
\hline $\mathrm{N} 1 / 65$ & Northern-Norway \\
\hline N2 & Val de Nomnom, Switzerland \\
\hline $\mathrm{P} 2$ & Piano dei Canali, Switzerland \\
\hline $\mathrm{S} 10$ & Triglav, Slovenia \\
\hline $\mathrm{S} 11$ & Triglav, Slovenia \\
\hline S15 & Triglav, Slovenia \\
\hline S19 & Triglav, Slovenia \\
\hline $\mathrm{S} 20$ & Triglav, Slovenia \\
\hline S5 & Triglav, Slovenia \\
\hline $\mathrm{U} 2 / 1$ & Sibay, Russia \\
\hline $\mathrm{U} 4 / 5$ & Novaja Zemlja, Russia \\
\hline $\mathrm{U} 4 / 5$ & Novaja Zemlja, Russia \\
\hline $\mathrm{U} 4 / 5$ & Novaja Zemlja, Russia \\
\hline $\mathrm{Ua} 2$ & Unteralp, Switzerland \\
\hline $\mathrm{V} 2$ & Val Fredda, Italy \\
\hline
\end{tabular}

Table 2. Sequences of the used and designed primers

\begin{tabular}{|l|l|}
\hline Primer & Sequence: \\
\hline RhpB13 forward: & $\begin{array}{l}\text { 5'GTAAAACGACAACCAGTCTCAGCCCGCT } \\
\text { GCT 3' }\end{array}$ \\
\hline RhpB13 reverse: & 5'TGTCGGAGAGATGAGTGGTG3' \\
\hline RhpB14a forward: & $\begin{array}{l}\text { 5'GTAAAACGACGGCCAGTCAAGCTAGGTC } \\
\text { TCA 3' }\end{array}$ \\
\hline RhpB14a reverse: & 5'TAACCAAGGGAGGAACACCA3 \\
\hline RhpB14b forward: & $\begin{array}{l}\text { 5'GTAAAACGACGGCCAGTCAAGTGTCCCA } \\
\text { TTG3 }\end{array}$ \\
\hline RhpB14b reverse: & 5'GTGACCGGTTGACCTAGCTT3' \\
\hline M13*primer: & 5'GTAAAACGACGGCCAGT3' \\
\hline Tru1I bottom: & 5'TAGGTACGCAGTCTAC3' \\
\hline Tru1I top: & 5'CTCGTAGACTGCGTACC3' \\
\hline
\end{tabular}

cleaved with $X b a \mathrm{I}$ and $\mathrm{BamHI}$ to determine the presence of the insert. The reaction mixture contained $10 \times$ buffer FD (Fermentas, Biocenter, Hungary), 1 U XbaI, 1 U BamHI restriction enzymes (Fermentas, Biocenter, Hungary), $2 \mu \mathrm{l}$ 
plasmid (ca. $100 \mathrm{ng} / \mu \mathrm{l}$ ) in a final volume of $20 \mu \mathrm{l}$. First, the mixture was incubated at $37^{\circ} \mathrm{C}$ for $15 \mathrm{~min}$, then at $65^{\circ} \mathrm{C}$ for $10 \mathrm{~min}$. After gel electrophoresis the nucleotide sequences of positive samples were determined by BAYGEN Capillary Sequencing Platform. The resulting chromatograms were visualized using BioEdit (Hall, 1999) program (Figure 1. 7. step).

PrimerS were designed for microsatellite-containing DNA sequences by Primer3 Software v. 0.4.0 program (Untergrasser et al., 2012; Koressaar \& Remm, 2007). The optimal annealing temperature of the primers were determined by gradient PCR. Two $\mu$ g genomic DNA (B2) was used for gradient PCR amplification in $20 \mu \mathrm{l}$ reaction volume containing $2 \mu \mathrm{l}$ GreenTaq 10xbuffer (Fermentas, Biocenter, Szeged, Hungary), $0.4 \mu \mathrm{l} 10 \mathrm{mM}$ dNTP mix, $0.5 \mu \mathrm{l} 10 \mu \mathrm{M}$ forward and $0.510 \mu \mathrm{M}$ reverse primer, $0.15 \mathrm{U}$ DreamTaq DNA polymerase (Fermentas, Biocenter, Szeged, Hungary) and $15.45 \mu$ distilled water. The PCR thermal profile was the same as previously described exept the different primer annealing temperature.

At last, the genetic variability of the developed microsatellite markers was studied on different individuals of $R$. rosea populations (Figure 1. 8. step). The $20 \mu \mathrm{l} \mathrm{PCR}$ mixture contained $2 \mu \mathrm{l}$ DreamTaq 10xbuffer (Fermentas, Biocenter, Szeged, Hungary), $0.4 \mu \mathrm{l} 10 \mathrm{mM}$ dNTP, 0.4 $\mu \mathrm{l} 10 \mu \mathrm{M}$ forward, $0.5 \mu \mathrm{l} 10 \mu \mathrm{M}$ reverse and $0.3 \mu \mathrm{l} 10 \mu \mathrm{M}$ M13* primer (Table 2), 0.15 U DreamTaq DNA polymerase (Fermentas, Biocenter, Szeged, Hungary), ca. $2 \mu \mathrm{g}$ genomic DNA and $15.25 \mu \mathrm{l}$ distilled water. The M13* PCR primer is 5' FAM fluorescent labelled oligonucleotide, which is needed to detect the size of the DNA fragments. The thermal profile of the PCR was the same as above. On the basis of gel electrophoresis the selected fragments were run in an automated sequencer ABI PRISM 3100 Genetic Analyzer (Applied Biosystems, Foster City, CA, USA). The obtained chromatograms were evaluated by Peak Scanner Software v 1.0 program (Applied Biosystems, Foster City, CA, USA) (Figure 1.9. step).

\section{Results}

The aim of this study was to develop novel microsatellite markers for $R$. rosea. The concentration of the isolated DNA was between 100-200 ng/ $\mu \mathrm{l}$. According to the agarose gel electrophoresis the best quality DNA was the S5 (135,7 ng/ $\mu \mathrm{l})$. This was chosen and digested with TrulI restriction enzyme. Adaptors were ligated to the sticky ends allowing the resulting fragments to be amplified (Figure 2). The (CA) containing fragments were selected by magnetic selection based on biotin-streptavidin linkage. Following the cloning of the resulting products one hundred six colonies were checked by colony PCR. The positive samples were selected based on gel electrophoresis. In those cases where amplification occurred, different sizes of DNA fragments were detected. Forty-four of the positive colonies were propagated in liquid culture and plasmids were isolated from them (Figure 3). To ensure that inserts of different size were cloned the isolated plasmids were cleaved. Finally, sequence analysis of fortythree plasmids was carried out.

Out of the forty-three sequenced samples only three contained microsatellite regions, however neither of them contained the aimed $(\mathrm{CA})_{\mathrm{n}}$ repeats. The identified loci were named as RhpB13 (TTGATTC) $)_{5}$, RhpB14a (GGA) $)_{5}$ and RhpB14b $(\mathrm{GGT})_{3}(\mathrm{GGA})_{3}$. Primer pairs were developed for the flanking regions of these 3 microsatellites (Table 2). Applying $53^{\circ} \mathrm{C}$ annealing temperature all three loci could be amplified (Figure 4). For RhpB14b primer pair $53^{\circ} \mathrm{C}$ proved to be satisfactory, but in the case of RhpB14a and RhpB13 markers the amplification was weak so further optimization was carried out by gradient PCR with V2 genomic DNA. Finally, $63^{\circ} \mathrm{C}$ as the optimal annealing temperature (Figure 5) was chosen. For RhpB13 optimal reaction conditions could not be determined.

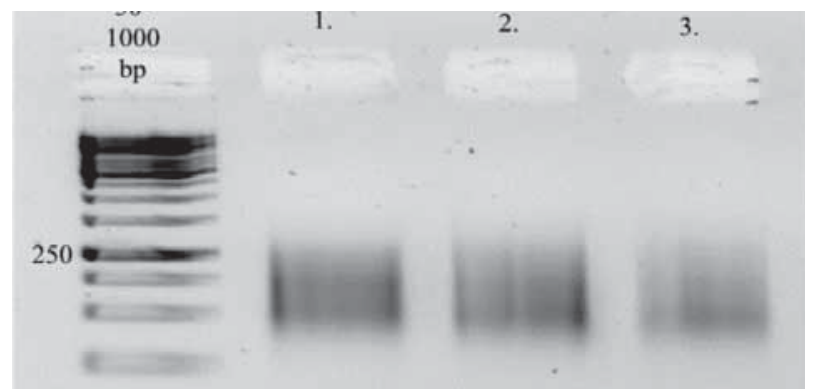

Figure 2. Electrophoretic gel photo of the PCR products after the digestion with Tru1I restriction endonuclease followed by adaptor ligation. First lane is 50 bp Gene Ruler (Fermentas, Biocenter, Hungary). 1-3 lanes mean different amount of template DNA: $0.75 \mu \mathrm{l}, 1.5 \mu \mathrm{l}$ and $2.5 \mu \mathrm{l}$. As a result, many, different fragments were amplified. The work was continued with the second sample.

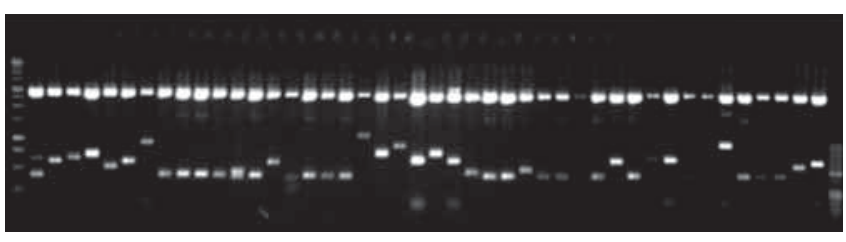

Figure 3. Restriction cleavage of plasmids purified from transformant colonies. First lane is $1 \mathrm{kB}$ Gene Ruler (Fermentas, Biocenter, Hungary) and the last lane is 50 bp Gene Ruler (Fermentas, Biocenter, Hungary). Plasmids are about 3000 bp while the inserts have different lengths. Out of forty-four plasmids forty-three were send to sequence analysis.

In the last step of the marker development the designed primers were tested on several $R$. rosea specimens originated from different sites. The sizes of the amplified microsatellite fragments were determined by fragment length analysis. The amplification was sufficient to give information on the polymorphism of the locus, but not with the desired reliability. Rhodiola rosea is a diploid, outcrossing species and as such one or two different microsatellite alleles were expected with high proportion of heterozygote individuals. Table 3 shows that in case of some samples three fragments were detected. This means that the primer pairs annealed to multiple loci. Based on the fragment length analysis RhpB14a amplified 
the same fragment sizes in each sample meaning that the locus is not polymorphic. With primers designed for both RhpB14b and RhpB13 three fragments were amplified in most of the cases. One of these was constantly present, while size variability was observed in the other two fragments. The performance of the RhpB14b and RhpB13 markers should be further improved, but two novel polymorphic markers were found in the genome of $R$. rosea.

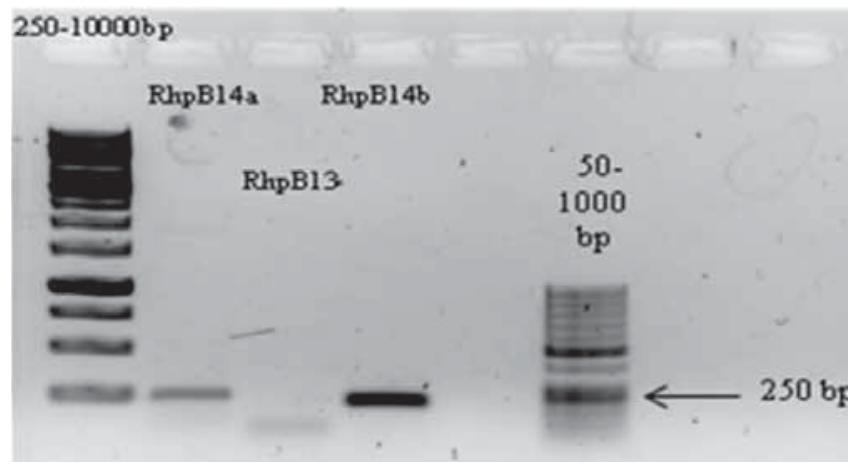

Figure 4. Test $\mathrm{PCR}$ with the designed primers at $53^{\circ} \mathrm{C}$. The amplification with RhpB14b was satisfactory, but the other two needed to be optimised

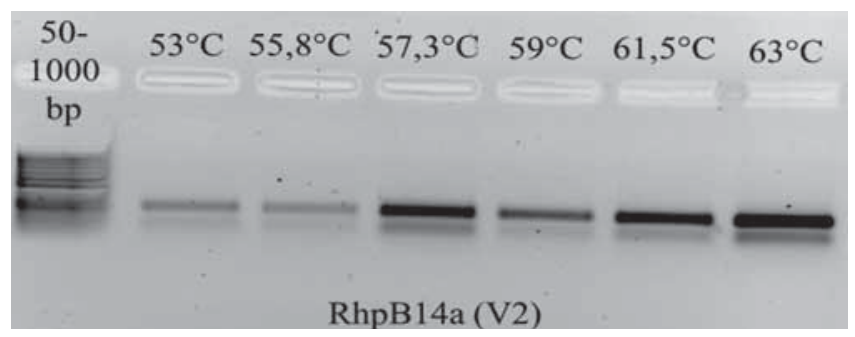

Figure 5. Gradient PCR of RhpB14a primer with V2 genomic DNA sample. First lane is 50 bp Gene Ruler (Fermentas, Biocenter, Hungary). The amplified fragments were at $250 \mathrm{bp}$ with different annealing temperature of the primer

Table 3. Result of the fragment length analysis

\begin{tabular}{|c|c|c|c|}
\hline DNA & \multicolumn{3}{|c|}{ RhpB13 primer (bp) } \\
\hline $\mathrm{N} 1 / 65$ & 237 & 223 & 272 \\
\hline $\mathrm{U} 4 / 5$ & 216 & 223 & 258 \\
\hline S10 & & 223 & 258 \\
\hline S5 & 237 & 223 & 272 \\
\hline $\mathrm{U} 4 / 5$ & 151 & 223 & 160 \\
\hline $\mathrm{U} 2 / 1$ & 216 & 223 & \\
\hline DNA & \multicolumn{3}{|c|}{ RhpB14a primer (bp) } \\
\hline $9 / 134$ & 247 & 238 & \\
\hline B2 & 247 & 238 & \\
\hline S19 & 247 & 238 & 232 \\
\hline $\mathrm{Ua} 2$ & 247 & 238 & 229 \\
\hline $\mathrm{P} 2$ & 247 & 238 & 229 \\
\hline N2 & 247 & 238 & \\
\hline DNA & \multicolumn{3}{|c|}{ RhpB14b primer (bp) } \\
\hline $9 / 134$ & 180 & 214 & 244 \\
\hline A3 & 209 & 214 & \\
\hline B3 & 180 & 214 & 189 \\
\hline S20 & 203 & 214 & 248 \\
\hline $\mathrm{U} 4 / 5$ & 180 & 214 & 197 \\
\hline $10 / 111$ & 203 & 214 & \\
\hline
\end{tabular}

\section{Discussion}

Today microsatellites are the most widely used molecular markers. They have several advantages compared to dominant markers like RAPD or AFLP, namely the codominant nature, locus specificity, good reproducibility and high polymorphism (Powell et al., 1996). The main limitation of the application of microsatellite technology is indeed its locus specificity. Microsatellite regions need to be isolated de novo from species being examined for the first time (Sudheer et al., 2010). The method of fast isolation by AFLP of sequences containing repeats (FIASCO) published by Zane et al. (2002) is the most widespread technique.

Zini et al. (2009) developed 8 microsatellite markers for $R$. rosea by the FIASCO method. In their work out of ninety-six colonies, thirty-seven contained microsatellite loci. Out of twenty three primer pairs designed 15 amplified DNA fragments but three Markers were monomorphic and four Markers pronounced multi-banding pattern. The further eight microsatellite loci were polymorphic. As comparison, to the work of Zini et al. (2009) out of the forty-three sequenced clones three contained microsatellite regions in our study. One of them was monomorphic but the other two were polymorphic.

Since the results at each check point were in line with the expectations, theoretically all the samples should have contained tandem repeat motives. The unexpectedly low proportion of microsatellite-containing sequences might be due to the fact that the applied oligonucleotide labelled with biotin was too short, hence hybridized also to stretches that did not contain $(\mathrm{CA})_{\mathrm{n}}$ regions. The possible solution to overcome this problem may be a longer oligonucleotide labelled with biotin: Sudheer et al. (2010) used oligonucleotides containing the dinucleotide motif 15-times or Zhang et al. (2008) used oligonucleotids containing dinucleotides repeated 17 times or trinucleotides repeated 12 times. However, the drawback of such solution would be that the genome contains considerably lower number of complementary sequences for longer oligonucleotides; therefore the hybridization would occur at a lower rate. Another possibility is to use two biotinylated oligonucleotids simultaneously during the enrichment process similarly to Sudheer et al. (2010).

A further possible cause of the low proportion of microsatellite-containing sequences may arise from not fully appropriate conditions for magnetic-selection, these are, however, difficult to be optimized. Yang et al. (2009) used the desired microsatellite motif as primer in the colony PCR, thus ensuring a more sensitive selection. Another way to increase the number of microsatellite-containing fragments could be used Southern blot following the colony PCR, which should be performed using radioactive labelled probes, thus ensuring a more sensitive selection.

Since the number of microsatellites occurring in the genome depends on the size of the genome of the organism (Tóth et al., 2000), which is not known in case of $R$. rosea, it is difficult to draw reliable conclusions with regard to the success rate of our study. 


\section{References}

Agarwal, M., Neeta, M. \& Shrivastava, H. P. (2008): Advances in molecular marker techniques and their applications in plant sciences. Plant Cell Reports, 27 (4): 617-631.

Behera, T. K., Gaikward, A. B., Singh, A. K. \& Staub, J. E. (2008): Relative efficiency of DNA markers (RAPD, ISSR and AFLP) in detecting genetic diversity of bitter gourd (Momordica charantia L.). Journal of the Science of Food and Agriculture, 88 (4): 733-737.

Blomkvist, J., Taube, A. \& Larhammar, D. (2009): Perspective on Roseroot (Rhodiola rosea) studies. Planta Medica, 75 (11): $1187-1190$.

Bloor, P. A., Barker, F. S., Watts, P. C., Noyes, H. A. \& Kemp, S. J. (2001): Microsatellite libraries by enrichment: http://www.liv. ac.uk/ kempsj/genomics.html.

Brown, R. P., Gerbarg, P. L. \& Ramazanov, Z. (2002): Rhodiola rosea - A phytomedicinal overview. HerbalGram, 56: 40-52.

Chiorghita, G., Hartan, M., Maftei, D. E. \& Nicuta, D. (2011): Some considerations regarding the In Vitro culture of Rhodiola rosea. Romanian Biotechnological Letters, 16 (1): 5902-5908.

Galambosi, B. (2005): Rhodiola rosea L., from wild collection to field production. Medicinal Plant Conservation, 11: 31-35.

Gupta, P. K., Balyan, H. S., Sharma, P. C. \& Ramesh, B. (1996): Microsatellites in plants: A new class of molecular markers. Current Science, 70 (1): 45-54.

Gupta, P. K., Roy, J. K. \& Prasad, M. (2001): Single nucleotide polymorphism (SNPs): A new paradigm for molecular marker technology and DNA polymorphism detection with emphasis on their use in plants. Current Science, 80 (4): 524-535.

György, Z., Vouillamoz, J.F., Ladányi, M. \& Pedryc, A. (2014): Genetic survey of Rhodiola rosea L. populations from the Swiss Alps based on SSR markers. Biochemical Systematics and Ecology, 54: $137-143$.

Hall, T. A. (1999): BioEdit: a user-friendly biological sequence alignment editor and analysis program for Windows 95/98/NT. Nucleic Acids Symposium Series, 41: 95-98.

Hegi, G. (1963): Rhodiola, Rosenwurz. In: Hegi, G. (ed.) Illustrierte Flora von Mitteleuropa, Band IV/2, Lieferung 2/3, zweite völlig neubearbeitete Edn., Hamburg/Berlin, 99-102.

Kelly, G. S. (2001): Rhodiola rosea: A possible plant adaptogen. Alternative Medicine Review, 6 (3): 293-302.

Khanum, F., Singh, A. B. \& Singh, B. (2005): Rhodiola rosea: A versatile adaptogen. Comprehensive Reviews in Food Science and Food Safety, 4 (3): 55-62.

Koressaar, T. \& Remm, M. (2007): Enhancements and modifications of primer design program Primer3. Bioinformatics, 23 (10): 1289-91.

Kylin, M. (2010): Genetic diversity of Roseroot (Rhodiola rosea L.) from Sweden, Greenland and Faroe Islands. Dissertation, Swedish University of Agricultural Sciences (Alnarp), Sweden.

Ohba, H. (1981): A revision of Asiatic species of Sedoideae (Crassulaceae): part 2. Rhodiola (subgen. Rhodiola sect. Rhodiola).
Journal of the Faculty of Science of the University of Tokyo, 13 (1): 65-119.

Ohba, H. (1989): Biogeography of the genus Rhodiola (Crassulaceae), with special reference to the Floristic Interaction between the Himalaya and Arctic Region. In: Ohba, H. (ed.) Current Aspects of Biogeography in West Pacific and East Asian Regions, University of Tokyo, 1: 115-133.

Sudheer, P. D. V. N., Rahman, H., Mastan, S. G. \& Reddy, M. P (2010): Isolation of novel microsatellites using FIASCO by dual probe enrichment from Jatropha curcas L. and study on genetic equilibrium and diversity of Indian population revealed by isolated microsatellites. Molecular Biology Reports, 37 (8): 3785-3793.

Padmanabhan, S., Banerjee, S. \& Mandi, N. (2011): Screening of Bacterial Recombinants: Strategies and Preventing False Positives. In: Brown, G. (ed.) Molecular Cloning - Selected Applications in Medicine and Biology. InTech pp. 1-14.

Panossian, A., Wikman, G. \& Sarris, J. (2010): Rosenroot (Rhodiola rosea): Traditional use, chemical composition, pharmacology and clinical efficacy. Phytomedicine, 17 (7): 481-493.

Powell, W., Morgante, M., Andre, C., Hanafey, M., Vogel, J., Tingey, S. \& Rafalski, A. (1996): The comparison of RFLP, RAPD, AFLP and SSR (microsatellite) markers for germplasm analysis. Molecular Breeding, 2 (3): 225-238.

Tasheva, K. \& Kosturkova, G. (2012): The role of biotechnology for conservation and biologically active substances production of Rhodiola rosea: endangered medicinal species. The Scientific World Journal, 2012: 1-13.

Tóth, G., Gáspári, Z. \& Jerzy, J. (2000): Microsatellites in different eukaryotic genomes: survey and analysis. Genome Research, 10 (7): 967-981.

Untergrasser, A., Cutcutache, I., Koressaar, T., Ye, J., Faircloth, B. C., Remm, M. \& Rozen, S. G. (2012): Primer3 - new capabilities and interfaces. Nucleic Acids Research, 40 (15): 115.

Wu, K., Jones, R., Danneberger, L. \& Scolnic, P. A. (1994): Detection of microsatellite polymorphisms without cloning. Nucleic Acids Research, 22 (15): 3257-3258.

Yang, J. B., Li, H. T., Li, D. Z., Liu, J. \& Gao, L. M. (2009): Isolation and Characterization of Microsatellite Markers in the Endangered Species Taxus wallichiana Using the FIASCO Method. HortScience, 44 (7): 2043-2045.

You, J., Liu, W., Zhao, Y., Zhu, Y., Zhang, W., Wang, Y., Lu, F. \& Song, Z. (2013): Microsatellite markers in Rhodiola (Crassulaceae), a medicinal herb genus widely used in traditional Chinese medicine. Applications in Plant Sciences, 1 (3): 1200219.

Zane, L., Bargelloni, L. \& Patarnello, T. (2002): Strategies for microsatellite isolation: a review. Molecular Ecology, 11 (1): 1-16.

Zhang, Y., He, J., Zhao, P. X., Bouton, J. H. \& Monterod, M. J. (2008): Genome-wide identification of microsatellites in white clover (Trifolium repens L.) using FIASCO and phpSSRMiner. Plant Methods, 4: 19

Zini, E., Clamer, M., Passerotti, S., Vender, C., Vendramin, G. G. \& Komjanc, M. (2009): Eight novel microsatellite DNA markers in Rhodiola rosea L. Conservation Genetics, 10 (5): 1397-1399. 